\title{
Grindelia ciliata (Astereae), \\ Thomas Nuttall, and the exploration of the American West
}

\begin{abstract}
Abigail J. Moore' (1)
' University of Oklahoma, Dept. of Microbiology and Plant Biology and Oklahoma Biological Survey, 770 Van Vleet Oval, Norman, OK 730 I 9 USA; abigail.j.moore@ou.edu
\end{abstract}

DOI: http://dx.doi.org/|0.53875/capitulum.01.2.08

\begin{abstract}
Early herbarium specimens collected on exploring expeditions are of both historical and scientific importance. Even when the specimen labels have little information, records of the expeditions can put the specimens into context. This is explored with an herbarium sheet of Grindelia ciliata with two specimens, one collected by Thomas Nuttall and the other collected by Samuel Woodhouse.
\end{abstract}

Keywords: Arkansas Territory, colonialism, Haplopappus, Wyethia

\section{INTRODUCTION}

In addition to being of scientific importance, herbarium specimens are also historic documents. Many of the earliest specimens collected in the US were made during military or colonial expeditions, which were often aimed at claiming territory for European settlers or resettling the people that were displaced by these territory claims. A sheet of Grindelia ciliata (Nutt.) Spreng. (Astereae: $\mathrm{PH}$ 00025850/PH 00009642; Figure I, see page 90) is a window into this period of American history.

This herbarium sheet is in the herbarium of the Academy of Natural Sciences of Philadelphia $(\mathrm{PH})$, which is now part of Drexel University. The Academy of Natural Sciences is one of the oldest natural history institutions in the United States, founded in 1812 , and houses important early collections from North America, including the famous Lewis and Clark herbarium and many type specimens for species collected across western North America (Lottinville, 1980; Mears, 1981).

The herbarium sheet includes two different collections of the same species, collected about 30 years apart and mounted on the same sheet, as was a common practice in herbaria at the time. Also, unfortunately common at the time, neither collection was dated, and the locality information was very approximate. However, we know more about these collections from their collectors' published writing and other information about the expeditions (Nuttall, I82 Ia, I82 Ib; Tomer \& Brodhead, 1992). 


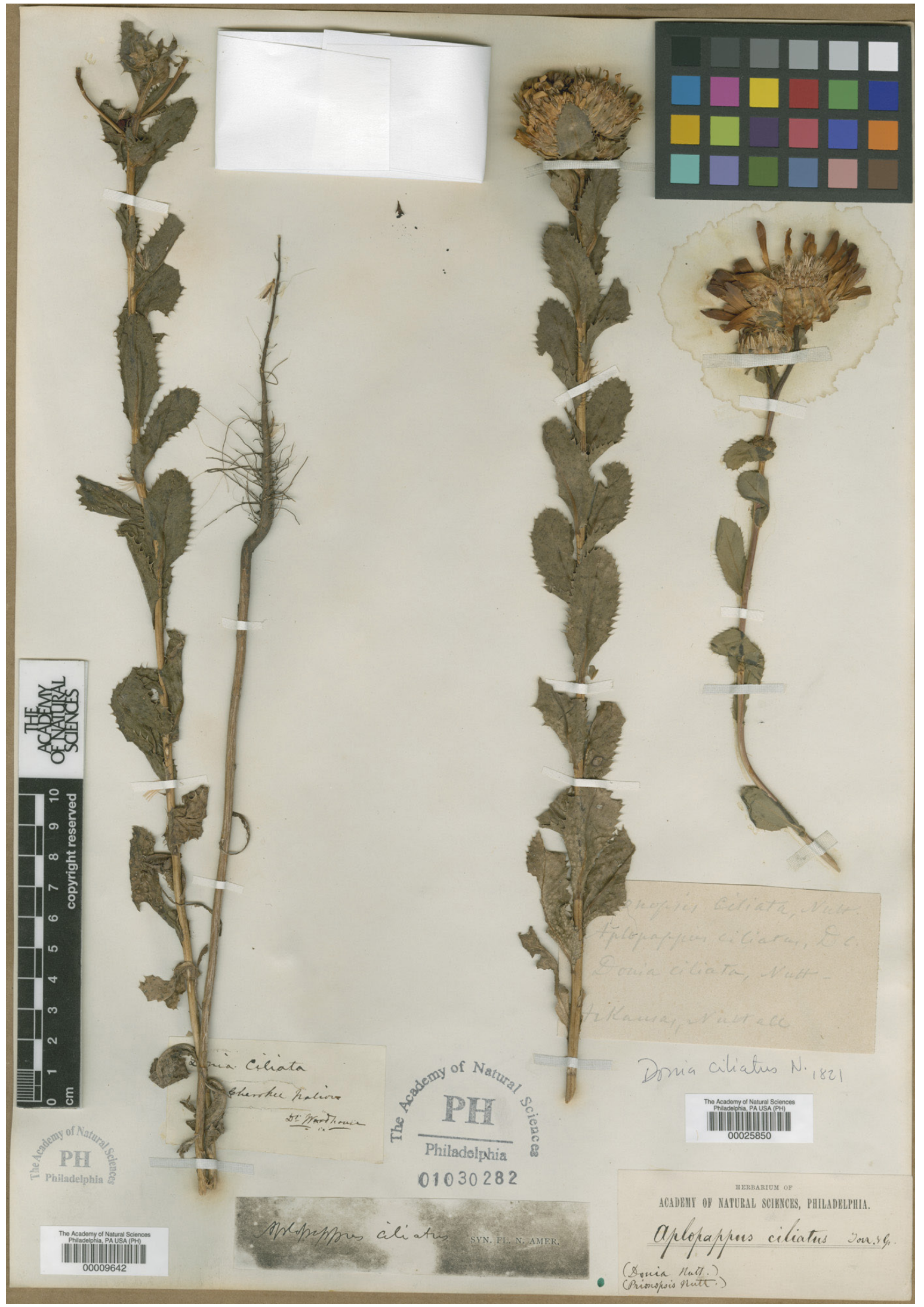

Figure I. Nuttall (PH 00025850) and Woodhouse (PH 00009642) specimens of Donia ciliata Nutt., now Grindelia ciliata (Nutt.) Spreng. Image copyright the Academy of Natural Sciences of Drexel University. 


\section{NUTTALL'S COLLECTION}

The earlier collection, located on the right, was collected by Thomas Nuttall (Figure 2) and was part of the original material of Donia ciliata Nutt. Nuttall was a largely self-taught botanist and ornithologist who made several expeditions into the western territories of the United States between 1809 and 1836 (Graustein, 1967; Lottinville, 1980; Isely, I994; Tyrl \& Shryock, 20I3). Nuttall travelled both with large parties, including Nathaniel Wyeth's expedition to the northwestern territories of the United States, and solo. During his travels, Nuttall was a copious collector. He would frequently collect plant material, including herbarium specimens and seed or bulbs to later sell, and a range of animal specimens, from birds to mollusks, all the while making notes on the local geology.

At the time that Nuttall went through presentday Oklahoma, he traveled with various people, including fur traders and people in the U.S. Army. From his description, it is clear that Nuttall saw G. ciliata in several places, although it is unclear where this collection was actually found. The species was mentioned once in his published diaries: "Amongst several other new plants, I found a very curious Gaura, an undescribed species of Donia, of Eriogonum, of Achyranthes, Arundo, and Gentian" (Sept. 8, 1819; Nuttall, I82Ia: 230-232). This was on what he called the Great Salt River, and is now known as the Cimarron River, a tributary of the Arkansas River. It seems likely it was in present day Pawnee or Payne County (Lottinville, 1980: 222). This was land that, at the time, had been given by treaty to the Osage Nation (Nuttall, I82 I a; Kappler, 1904). In his published diaries, Nuttall writes about his encounters with members of the Osage Nation, as well as their customs, history, and relations with the Cherokee and Pawnee Nations that are also in the area (Nuttall, I82 Ia).

Nuttall was one of the earliest people in the western territories to not only collect both plants and animals, but to also describe them. At the time, it was more common for expedition naturalists or leaders to collect specimens and to give them to specialists to describe, who were not themselves familiar with the plants and animals in the field and whose descriptions were entirely based on the specimens themselves and any notes taken by the

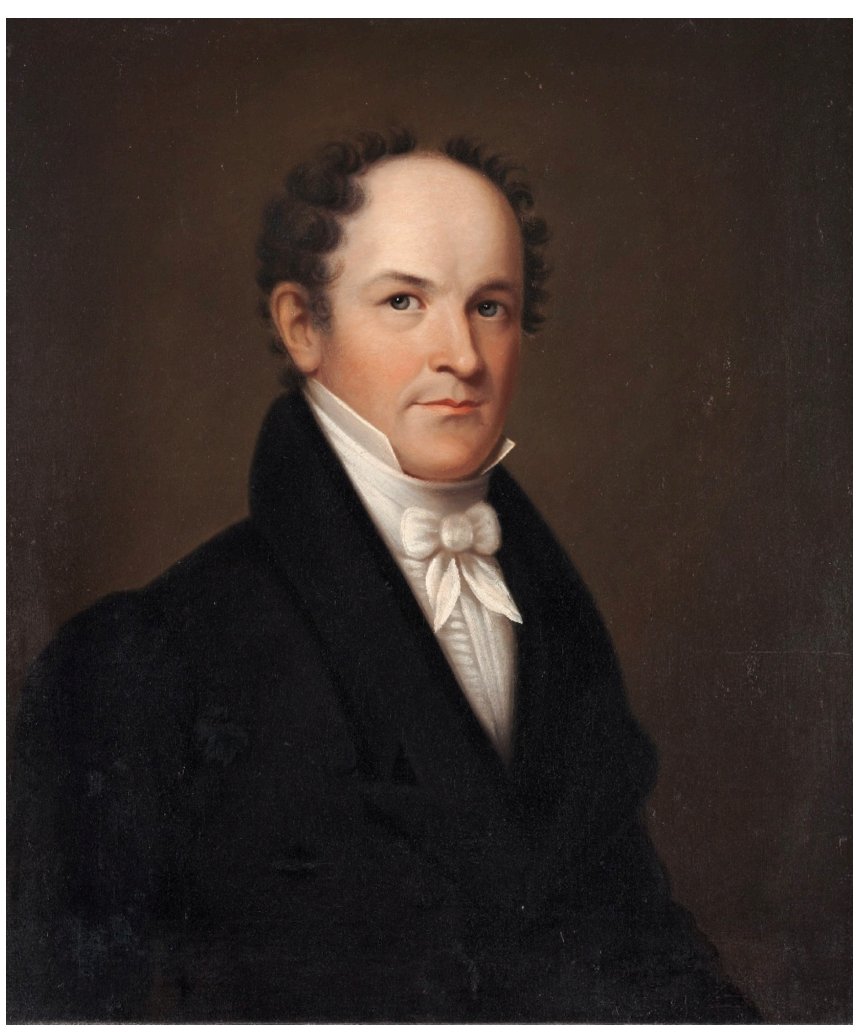

Figure 2. Thomas Nuttall (1786-|859), Harvard University Portrait Collection, Gift of Professor Edward Tuckerman to Asa Gray for the University, 1865, Photo (c) President and Fellows of Harvard College, HI 85

collectors. For example, Nuttall described the plants from an earlier Wyeth expedition, naming what he presumably considered the nicest plant Wyeth collected after him, Wyethia helianthoides Nutt. (Heliantheae: Engelmanniinae; Figure 3, Figure 4) Nuttall, 1834).

In Nuttall's descriptions of the plants he collected himself, he was not limited to the information on the labels and from the specimens but could also draw on his observations of the plants in the field. This is fortunate, because often his labels only contain a brief mention of the place, but no date or year. (In this case, the collection is simply labeled "Arkansas", which probably served as a general locality for his entire expedition, since he was traveling in what was then known as Arkansas Territory, although it could have been somewhat more specific and referred to the Arkansas River.) He gives much more information in his formal description of the species: "On the alluvial banks of the Arkansa, and Great Salt River.-Flowering time, from August to October" (Nuttall, I82 Ib: | |9). 


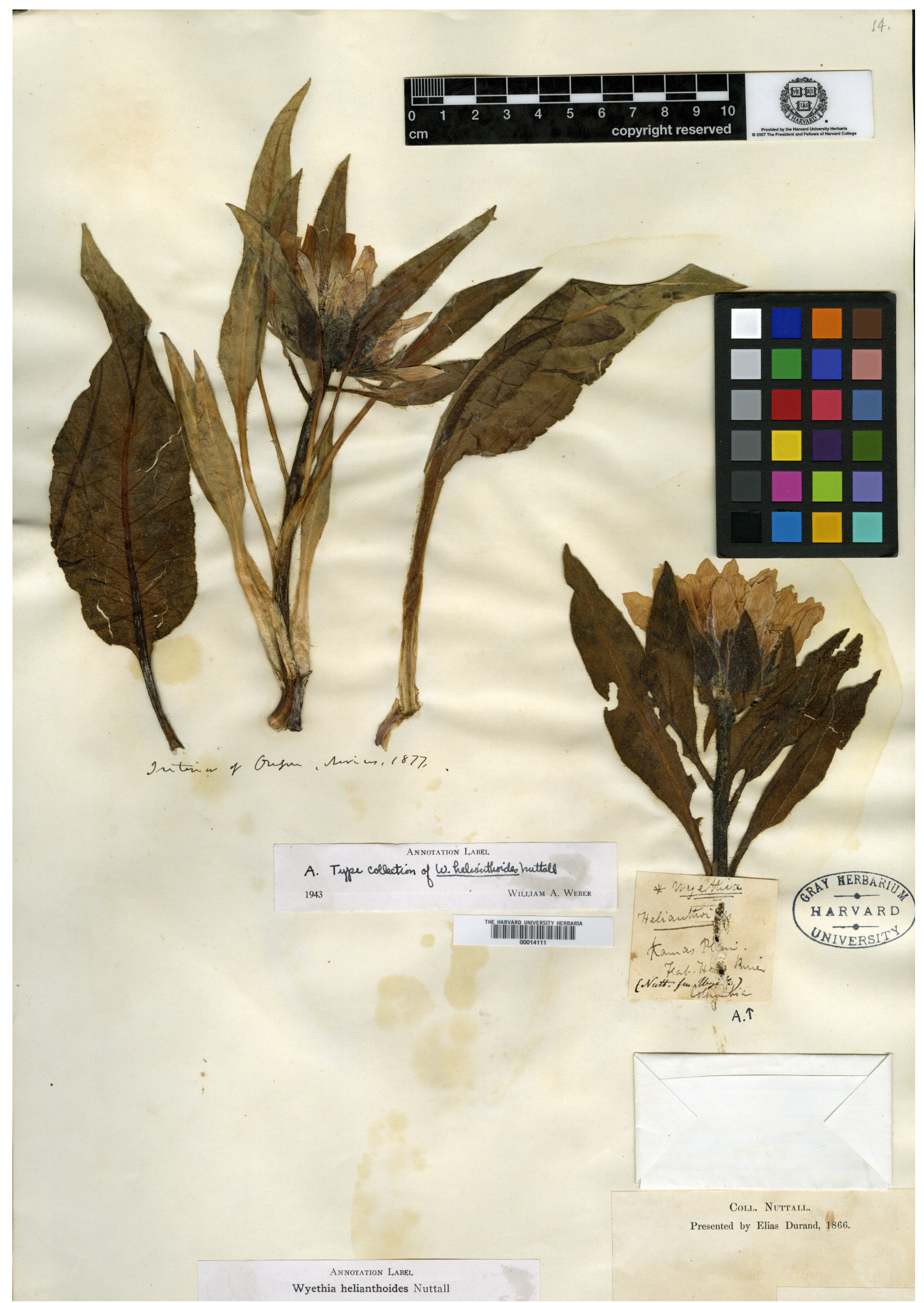

Figure 3. Wyeth specimen of Wyethia helianthoides on right, specimen from another collector on left (GH $000 / 4 \mathrm{I} I \mathrm{I})$. Image from the Gray Herbarium of Harvard University. 


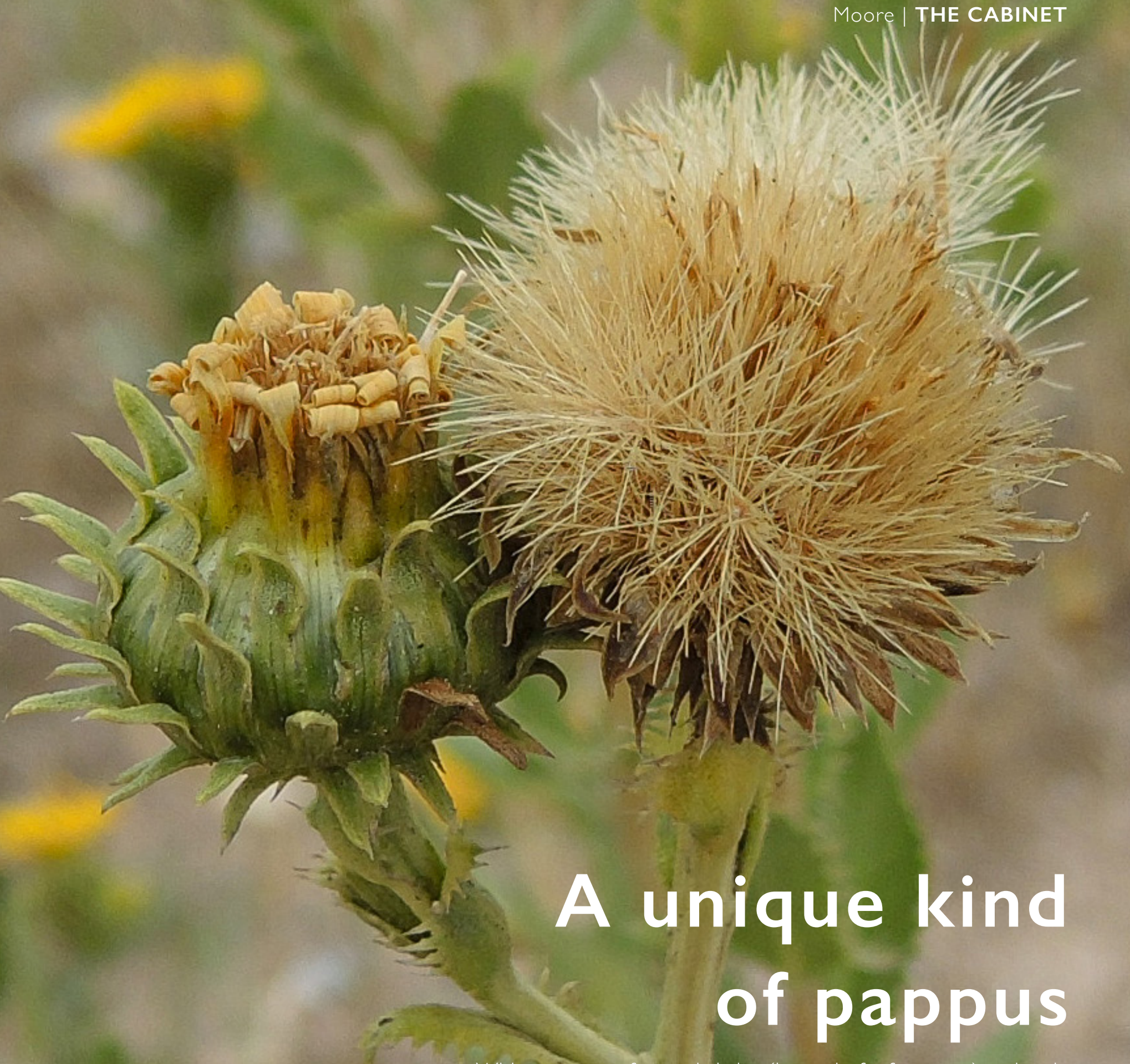

With a pappus of many bristles (instead of a few awns) and resin that is kept within the leaves, Grindelia ciliata is morphologically distinct from other members of the genus. It is currently found in disturbed, open habitats throughout Kansas, Oklahoma,

Grindelia ciliata from Martin County, Texas, USA. Photo by Abigail Moore

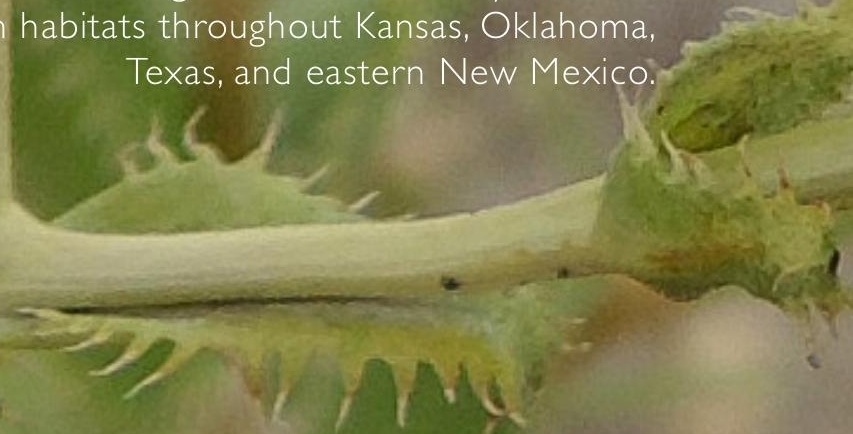

CAPITULUM | VOLUME I (2) | JANUARY 2022 


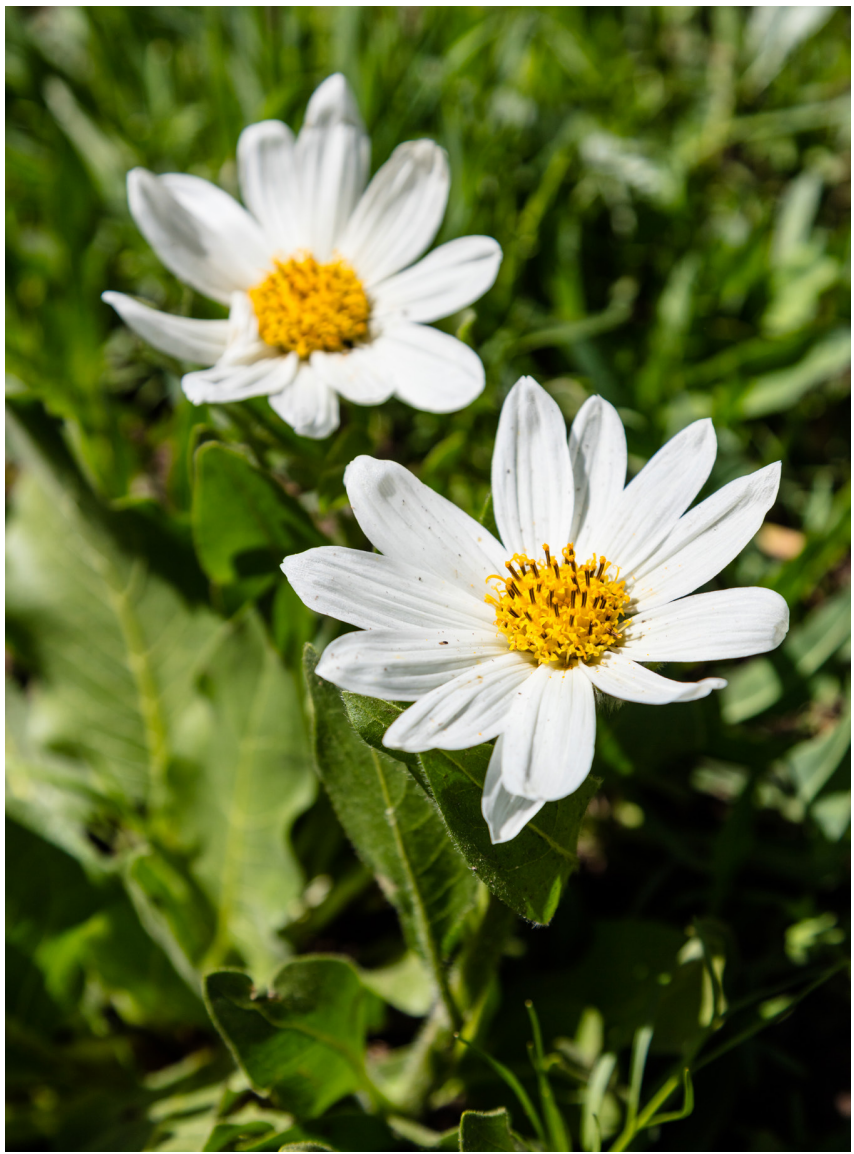

Figure 4. Wyethia helianthoides, Yellowstone National Park. Photo: J. W. Frank, National Park System (USA).

Despite the locality information, it is not completely clear whether Nuttall's collection was actually from wild material or was grown from seed (or whether the two branches were even collected in the same place). The type locality is, "Cultivated in the garden of the University of Pennsylvania" (Nuttall, I 82 l b: I19). The specimen at Kew (K) is indeed labeled "Seeds from Arkansa. Nuttall", and it may be that Nuttall only collected seed, and not herbarium specimens, of $G$. ciliata on his travels in Arkansas Territory.

\section{WOODHOUSE'S COLLECTION}

The second collection on the sheet was by Samuel W. Woodhouse on the U.S. Army Corps of Topographical Engineers Sitgreaves Expedition, which took place from 1849 to I85I. Woodhouse was a surgeon and naturalist with the U.S. Army as well as a member of the Academy of Natural
Sciences in Philadelphia (Tyrl \& Shryock, 20/3). Although Woodhouse himself was based in Philadelphia, he gave most of his plant specimens to John Torrey to describe, so they are now at the New York Botanical Garden (NY). Torrey wrote the account of the botany of the expedition (Torrey, 1853), although it does not include a full list of the plants collected or reference to this species. It is not clear who determined Woodhouse's specimen of $G$. ciliata, but the fact that it was called Donia ciliata, which was not the accepted name at the time, indicates that it was not determined by Torrey, who would have used the current name.

The locality of Woodhouse's collection is "Cherokee Nation". The objective of the first part of the Sitgreaves Expedition was to survey the boundary between lands given to the Muscogee (then called Creek) and Cherokee Nations. Two surveys of this boundary took place in July through October of 1849 and July through August of 1850 (Tomer \& Brodhead, 1992). These areas were in the vicinity of Nuttall's localities along the Arkansas and Cimarron Rivers (then called the Red Fork of the Arkansas River). They had been taken away from the Osage Nation by treaty in 1825 (Kappler, 1904) and given to the Muscogee and Cherokee Nations after they were forcibly displaced from their ancestral homelands. Instead of following the rivers, as Nuttall did for that part of his expedition, the Sitgreaves Expedition traveled straight across country, along the boundary they were surveying. While Woodhouse's diary of the expedition is now published (Tomer \& Brodhead, 1992), his natural history observations are largely confined to birds and other vertebrates, as these were his primary interest, and this species was not mentioned.

\section{NOMENCLATURAL HISTORY}

The herbarium sheet as a whole has three different names, none of which is the currently accepted name, Grindelia ciliata. Nuttall originally described the plant as Donia ciliata (Nuttall, | $82 \mathrm{Ib}$ ). The genus Donia R. Br. was described in 1813 (Brown, 1813) for another species that is now also considered to be part of Grindelia Willd., D. glutinosa (Cav.) R. Br. (originally described as Aster glutinosus Cav., now called G. glutinosa (Cav.) Dunal). Once Dunal ( 8 |9) realized that Grindelia and Donia were synonyms, 


\section{A sanctuary \\ for pollinators}

Grindelia ciliata is important for pollinators such as this Euglossine bee, because it grows in disturbed areas where there are seldom any other good nectar plants. 
the name Donia gradually dropped from usage to be replaced by Grindelia, a change that was accepted by Nuttall for most of the species he originally placed in Donia, once he became aware of the name Grindelia (e.g., Nuttall, I 834, I 840).

Sprengel (1826) made the combination Grindelia ciliata. However, de Candolle ( 1836 ) instead put the species in Aplopappus Cass. (spelling later corrected to Haplopappus by Endlicher, 1837), commenting that Aplopappus was very similar in habit to Grindelia and was distinguished by pappus differences (with a pappus of numerous bristles instead of few awns; de Candolle, 1836). In Nuttall's later work, instead of putting this plant into Grindelia or Aplopappus, he placed it in a new monotypic genus, Prionopsis Nutt., but followed de Candolle by putting Prionopsis next to Aplopappus and distant from Grindelia (Nuttall, 1840).

The last annotation was presumably by Gray, for his Synoptical Flora of North America (Gray, I 884: 125). He put G. ciliata back into Aplopappus, but in its own section, section Prionopsis, and again commented that the species was similar vegetatively to Grindelia. Due to the pappus differences, G. ciliata continued to be accepted as part of either Haplopappus or Prionopsis for the next hundred years. However, micromorphological (Nesom et al., 1993) and molecular (Moore et al., 2012) data showed that it was clearly nested within Grindelia, and it is currently accepted as a member of that genus. In addition to being historical documents of the time they were collected, herbarium specimens continue to document the changes in scientific thought afterwards, through their annotation histories.

\section{ACKNOWLEDGEMENTS}

I thank M. Bonifacino, L. Roeble, E. Schilling, and one anonymous reviewer for important suggestions that greatly improved the manuscript and the Academy of Natural Sciences of Drexel University, Gray Herbarium, and the President and Fellows of Harvard College for permissions to use images.

\section{LITERATURE CITED}

Brown, R. 1813. Hortus Kewensis; or, a Catalogue of the Plants Cultivated in the Royal Botanic Garden at Kew. Ed. 2 5: 82. London: Richard Taylor and Co.

De Candolle, A.P. 1836. Prodromus Systematis Naturalis Regni Vegetabilis, sive Enumerato Contracta Ordinum, Generum, Specierumque Plantarum huc usque cognitarum, juxta methodi naturalis normas digesta.Vol. 5. Paris:Treuttel et Würtz.

Dunal, F. 1819. Note sur deux genres de plantes de la famille des composées. Mém. Mus. Hist. Nat. 5: 45-58.

Endlicher, S.F.L. 1837. Genera plantarum secundum ordines naturales disposita.Vienna: Fr. Beck Universitatis Bibliopolam.

Graustein, J.E. 1967. Thomas Nuttall, Naturalist: Explorations in America 1808-1841. Cambridge: Harvard University Press.

Gray, A. 1884. Synoptical Flora of North America Vol. I, Part 2: Caprifoliaceae-Compositae. New York: Ivison, Blakeman, Taylor, and Company.

Isely, D. 1994. One Hundred and One Botanists. Ames: lowa State University Press.

Kappler, C.J. 1904. Indian Affairs: Laws and Treaties, vol. 2, (Treaties).Washington: Government Printing Office.

Lottinville, S. (ed.). 1980. A Journal of Travels into the Arkansas Territory During the Year 1819. Norman: University of Oklahoma Press.

Mears, J.A. 198I. Guide to plant collectors represented in the herbarium of the Academy of Natural Sciences of Philadelphia. Proc. Acad. Nat. Sci. Philadelphia 133: |4|-165.

Moore, A.J., Bartoli, A., Tortosa, R.D., \& Baldwin, B.G. 2012. Phylogeny, biogeography, and chromosome evolution of the amphitropical genus Grindelia (Asteraceae) inferred from nuclear ribosomal and chloroplast sequence data. Taxon 61: $211-230$.

Nesom, G., Suh, Y., \& Simpson, B.B. 1993. Prionopsis (Asteraceae: Astereae) united with Grindelia. Phytologia 75: 341346.

Nuttall, T. 1821 a. A Journal of Travels into the Arkansas Territory During the Year 1819. Lottinville, S. (ed.), 1980, Norman: University of Oklahoma Press (originally A journal of travels into the Arkansa Territory, during the year 1819. Philadelphia:T.H. Palmer).

Nuttall, T. 182 Ib. A description of some new species of Plants, recently introduced into the gardens of Philadelphia, from the Arkansa territory. J.Acad. Nat. Sci. Philadelphia 2 ( I): | |4-123. 
Nuttall, T. 1834. A catalogue of a collection of plants made chiefly in the valleys of the Rocky Mountains or Northern Andes, towards the sources of the Columbia River, by Mr. Nathaniel T. Wyeth, and described by T. Nuttall. J. Acad. Nat. Sci. Philadelphia. 7: 5-60.

Nuttall, T. 1840. Descriptions of new species and genera of plants in the natural order of the Compositae, collected in a tour across the continent to the Pacific, a residence in Oregon, and a visit to the Sandwich Islands and Upper California, during the years 1834 and 1835. Trans. Amer. Philos. Soc. 7: 283-453.

Sprengel, C.P.J. 1826. Systema Vegetabilium, editio decima sexta. 3 Göttingen: Sumtibus Librariae Dieterichinae.

Tomer, J.S. \& Brodhead, M.J. (eds). 1992. A Naturalist in Indian Territory: The journals of S. W. Woodhouse, 1849-50. Norman: University of Oklahoma Press.

Torrey, J. 1853. Botany. Pp. I55-178 in: Sitgreaves, L. (ed.), Report of an Expedition down the Zuñi and Colorado Rivers. Washington, D.C.: U.S. Army Corps of Topographical Engineers.

Tyrl, R.J. \& Shryock, P.A. 20 I 3. A cavalcade of field botanists in Oklahoma-Contributors to our knowledge of the flora of Oklahoma. Oklahoma Native Plant Record 13: 55-100. https:// doi.org// 0.22488/okstate. I 7. 100099 